\title{
Diagnosa Radiografi Kasus Hernia pada Kucing
}

\author{
Dian Vidiastuti
}

Bagian Klinik Veteriner, Fakultas Kedokteran Hewan, Universitas Brawijaya

ABSTRAK: Hernia terjadi akibat kelemahan dinding abdomen sehingga memungkinkan bagian usus atau organ lain melewati celah abdomen mengakibatkan penonjolan. Dua ekor kucing jantan, berumur sekitar 3-4 bulan, menjalani pemeriksaan radiologi di Rumah Sakit Hewan Pendidikan Universitas Brawijaya. Gambaran radiografi kasus 1 gejala dyspnea dengan standar pandang left lateral menunjukkan usus terjepit masuk di dalam rongga thorax dengan diagnosa peritoneo-pericardial diaphragmatic hernia. Pada kasus 2 dengan gejala perut kanan membesar, tampilan radiografi standar pandang dorsoventral menunjukkan hernia inguinalis akibat trauma.

Kata kunci:

hernia inguinalis, kucing, peritoneo-pericardial diaphragmatic hernia, radiografi

\section{- PENDAHULUAN}

Hernia terjadi akibat kelemahan dinding abdomen sehingga memungkinkan bagian usus atau organ lain melewati celah dan menonjol. Hernia menyebabkan organ lain seperti vesika urinaria, usus besar, atau saraf terperangkap, menghasilkan konstipasi, gangguan urinari, atau fungsi seksual. Hal ini dikategorikan gawat darurat karena sebagian usus mengalami nekrotik, sehingga mengakibatkan peritonitis yang mengancam jiwa dan membutuhkan operasi segera (Pluta $e t$ al. 2011). Penegakan diagnosa hernia diafragmatika terutama berdasarkan pada radiografi (Debiak et al. 2009)

\section{- SINYALEMEN, ANAMNESA, DAN GEJALA KLINIS}

Berdasarkan data rekam medis di Rumah Sakit Pendidikan Fakultas Kedokteran Hewan Universitas Brawijaya periode Januari - Juni 2017, terdapat dua ekor anak kucing lokal berjenis kelamin jantan dirujuk untuk menjalani pemeriksaan radiografi karena salah satu kucing menunjukkan gejala gangguan pernafasan, sedangkan kucing yang lain diselamatkan pasca kecelakaan.

Kasus 1 adalah kucing jantan berumur 4 bulan dengan gejala klinis depresi dan dyspnea. Tidak ada riwayat trauma. Kasus 2 adalah kucing jantan berumur 3 bulan diselamatkan dari kecelakaan, terlihat adanya pembesaran perut, memiliki kelemahan ekstremitas belakang, tidak dapat berjalan dan nyeri pada palpasi. Posisi radiografi kasus 1 yaitu standar pandang lateral sedangkan standar pandang kasus 2 ventrodorsal untuk melihat kemungkinan terjadi fraktur.

\section{- HASIL DAN PEMBAHASAN}

Hasil analisa radiografi pada kasus pertama menunjukkan jantung membesar (skor intercostal space sebesar 6), bayangan jantung superimpose dengan loop usus tampak radiolucent. Garis diafragma discontinue akibat sebagian isi abdomen masuk ke dalam rongga thorax. Perpindahan loop usus yang berisi gas ke pericardial menyebabkan gangguan pernapasan. Diagnosa pada kasus ini yaitu peritoneopericardial diaphragmatic hernia (PPDH) (Gambar 1).

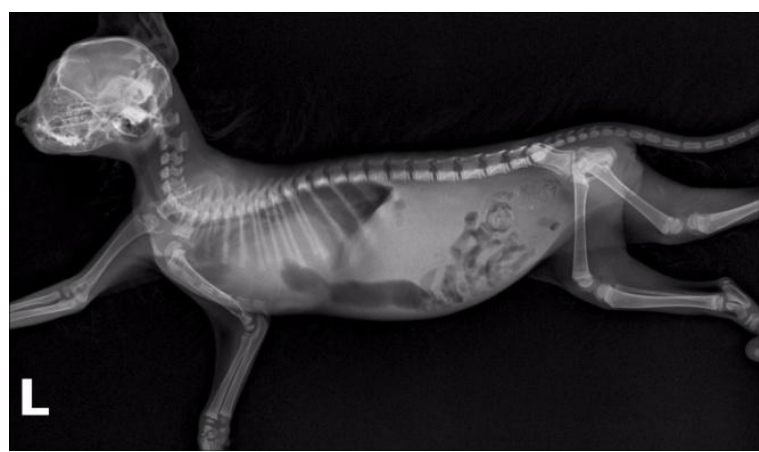

Gambar 1 Radiografi standar pandang left lateral kasus peritoneopericardial diaphragmatic hernia (PPDH). Hilangnya bayangan jantung dan loop usus berisi gas superimpose dengan jantung (kasus 1).

Radiografi dorsoventral menunjukkan pada kasus kedua terdapat hernia inguinalis. Perut kanan membesar menjepit kolon dan vesika urinaria. Kucing mengalami fraktur oblique pada diaphysis tulang femur kiri dan fraktur transversal

$\begin{array}{ll}\text { Diterima } & \text { : } 28 \text { Juli } 2017 \\ \text { Direvisi } & : 14 \text { Agustus } 2017 \\ \text { Disetujui } & \text { : } 29 \text { Agustus } 2017\end{array}$ 
pada tulang ilium (pelvis kanan) (Gambar 2).

Diagnosia banding peritoneo-pericardial diaphragmatic hernia (PPDH) dengan pembesaran jantung yaitu defek endokard, cacat jantung kongenital (misalnya patent ductus arteriosus, ventricular septal defects), cardiomyopathy dan efusi perikardial (Rexing dan Coolman 2004). Sebagian besar kasus hernia terjadi sejak lahir tetapi gejala klinis dapat terjadi pada beragam usia, tidak selalu muncul sejak dini bahkan tidak muncul sama sekali. Kasus yang dilaporkan oleh Debiak et al. (2009), usia timbulnya gejala klinis berkisar antara 4 minggu sampai 7 tahun, dengan diagnosis yang dilakukan pada tahun pertama kehidupan. Gejala klinis terkait dengan sistem gastrointestinal dan saluran pernafasan meliputi depresi dan dyspnea.

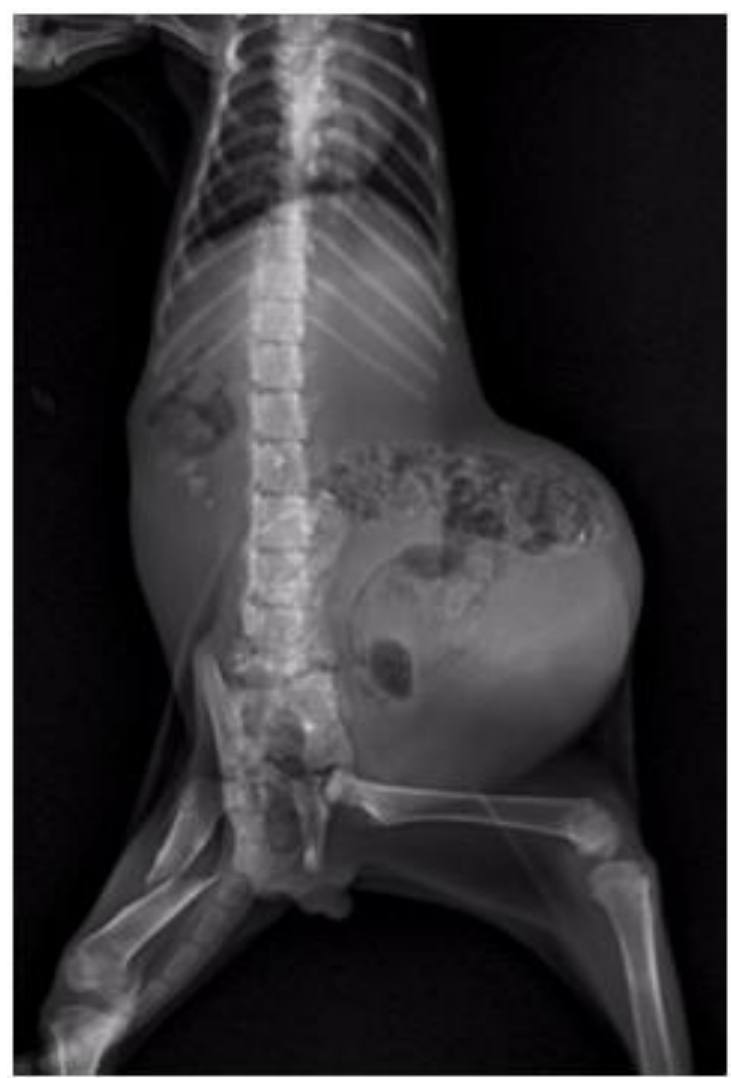

Gambar 2 Radiografi dorsoventral hernia inguinalis. Perut kanan membesar dengan loop usus dan vesika urinaria yang terjepit pada kanal hernia (kasus 2).

Hernia inguinalis akibat traumatik menjadi tantangan karena lemak menutupi kanal inguinalis sehingga sulit untuk dideteksi (Yool 2012). Kasus hernia inguinalis pada kucing dengan vesika urinaria yang terperangkap menyebabkan gangguan saluran urinari bagian bawah (Shaw et al. 2003). Tindakan koreksi bedah memberikan solusi cepat dan efektif jika kelainan yang ada ditemukan dengan segera (Neville-Towle dan Sakals 2015).

\section{- SIMPULAN}

Temuan radiografi menentukan jenis diagnosis banding dan menemukan adanya hernia dengan berbagai gejala klinis. Radiografi peritoneo-pericardial diaphragmatic hernia (PPDH) kongenital menunjukkan bahwa loop berisi gas ke perikardial, sementara gambaran radiografi hernia inguinalis menunjukkan pembesaran perut dengan vesika urinaria dan loop usus yang terjepit pada kanal hernia.

\section{- INFORMASI PENULIS}

Penulis untuk Korespondensi

dianvidiastuti@gmail.com

\section{- UCAPAN TERIMA KASIH}

Penulis mengucapkan terima kasih kepada Fakultas Kedokteran Hewan Universitas Brawijaya yang telah memberikan bantuan dana publikasi.

\section{- PUSTAKA ACUAN}

Debiak, P, Ojszczyk-Szczepaniak A, Komsta R. 2009. Diagnostics of canine peritoneal-pericardial diaphragmatic hernia (PPDH). Medycyna Wet. 65 (3): 181-183.

Neville-Towle J, Sakals S. 2015. Urinary bladder herniation through a caudoventral abdominal wall defect in a mature cat. Can Vet J. 56(9): 934-936.

Pluta RM, Burke AE, Golub RM. 2011. Abdominal Hernia. JAMA. 305(20): 2130.

Rexing JF, Coolman BR. 2004. A peritoneopericardial diaphragmatic hernia in a cat. Vet Med. 99: 314-318.

Shaw SP, Rozanski EA, Rush JE. 2003. Traumatic body wall herniation in 36 dogs and cats. J Am Anim, Hosp Assoc.39:35-46.

Smeak DD. 2003. Abdominal Hernia in Text book of small animal surgery. Missouri (US): Elsevier Science.

Yool DA. 2012. Small Animal Soft Tissue Surgery. Oxfordshire (UK): CABI. 